DOI https://doi.org/10.18551/rjoas.2018-05.10

\title{
EXTENSION AND CONSEQUENCE OF BURNOUT ANTECEDENT MODEL TO JOB SATISFACTION OF COLLEGE LECTURERS WHO CONCURRENT STRUCTURAL POSITION AT PRIVATE-OWNED UNIVERSITY IN ISLANDS OF AMBON, INDONESIA
}

\author{
Tamaela Eduard Yohannis* \\ Sekolah Tinggi Ilmu Administrasi Said Perintah, Indonesia \\ Hetharie Jondry Adrin \\ Sekolah Tinggi Ilmu Ekonomi dan Manajemen Rutu Nusa, Ambon, Indonesia \\ Huwae Victor Ernest \\ Universitas Pattimura, Indonesia \\ *E-mail: tamaelaeduard@gmail.com
}

\begin{abstract}
This research aims to describe and analyze the effects of the role conflict, the intrinsic motivation and an excessive workload to burnout and satisfaction level of college lecturers who concurrent structural position at Private-Owned University (PTS) in islands of Ambon. The result of hypothesis testing through confirmatory factor analysis and path analysis shows that intrinsic motivation and work overload are proven to significantly affect burnout level, and intrinsic motivation, role conflict and burnout are proven to significantly affect job satisfaction level.
\end{abstract}

\section{KEY WORDS}

Role conflict, intrinsic motivation, excessive workload, burnout, job satisfaction.

College Instructors as civitas academica will have a direct contact continuously with another individual, such as colleagues in their periodic meeting with their superiors, their coworkers, another lecturer, administration staff or students in various occasions such as in the class, seminars, counselling and many other events. However, for a lecturer with a high rate of direct contact from these daily routine, they will be more prone to suffer something that well know as "Burnout", which starts with some symptoms such as emotionally tired (low of emotional source such as compassion, empathy and attention), look down on people, become obnoxious and irritates other people and probably mark himself as incompetent and ineffective lecturer who dissatisfied with what their work.

This convictions are based on some scientific journal, for instance: Cordes and Dougherty (1993) in Low et al., (2001) state burnout is evidently occurs in various kind of job with various kinds of conditions. In line with them, Maslach also states that Burnout is closely related with a profession with service field of work such as a nurse, a teacher (a professor or a college instructor), or any social workers who meet their customers directly. Those professions which prone to burnout became a popular sample to study, some of the researchers who had researched them namely; Dubisky at al., (1992); Moncrief et al., (1997); Babakus at al., (1999); Brashear at al., (2000); Low at al., (2001); Zagladi, (2004) dan Harris at al., (2006). The last conviction is based on the burnout research to some elementary, junior high school and senior high school teachers as well as college instructor in America by Sweeney and Summers, (2002) who proves that not only college instructor but also teachers in general experience Burnout from work. According to those previous researches, college instructors are prone to burnout, both civil servants instructor (PNS) and private college instructor. Nevertheless, in this research the writers are more focused on the college instructor who have structural position at PTS in islands of Ambon.

Burnout that most likely be experienced by the college instructor who concurrent structural position at PTS in islands of Ambon, is undoubtedly caused by unfavorable 
conditions for the instructor. One of the conditions is a role conflict which is experienced by the college instructor in islands of Ambon. This phenomenon is in line with the result of empirical research by Dubisky at al., (1992) who determine that role conflict to sales person has an (negative) impact to job satisfaction level. This finding is supported by similar research by Brashear at al., (2000). Another factor which relatively affect burnout to the lecturer is the workload they have to bear. This claim is supported by the research by Shaw and Weekly, (1985) who explains that work overload positively affects perceive pressure. In line with Shaw and Weekly, (1985), Zagladi (2004) find that the workload, especially the excessive one, positively affects burnout, while role conflict does not affect burnout and emotional exhaustion (one of burnout's dimension) which significantly affect job satisfaction.

The other interesting factor related to burnout surprisingly comes from intrinsic motivation of the instructor. Brewer, 1994 (in Karatepe dan Tekinkus, 2006) explains that intrinsic motivation is one of the best key of the talented front-liner and his research shows that intrinsic motivation has negative impact to burnout (this result is also supported by empirical research Low at al., 2001). Therefore, it can be concluded that intrinsic motivation is a variable that decrease burnout intensity. The research gap used in this research are based on empirical research which are explained below. The first research gap has three references from past scientific researches. The first reference is by Babakus et al., (1999). The second reference is based on scientific research by Low et al., (2001). The last one is a model of conceptual research by Zagladi, (2004). Consequently, an ambivalent result can be seen as a research gap which can be explored further in this research. The ambivalent result refers to the research result by Low et al., (2001) who concludes that the effect of role conflict to burnout is positive. This result is also supported by Babakus et al., (1999) but not by Zagladi, (2004) which has negative effect.

The second research gap is based on a suggestion from past research by Dubisky et al., (1992) to research some element of job satisfaction from various countries. Moncrief et al., (1997) also suggests that future research should be focused on identifying antecedent and another factors as well as their impact as the antecedent of work pressure. Perrewe et al., (2002) dan Boswell et al., (2004) also suggest that future research would base on his research gap namely (1). Add another variables in burnout model. (3). Examining burnout dimension by conducting detailed research on the antecedent as well as the consequences from the burnout model, and Lankau et al., (2005) also suggests to study his research gap to analyze the influence of a mentor and the stress caused by mentoring activity as a significant cause of burnout which mainly related to role conflict and work overload as an obligation.

With the suggestions of those three past researches and the relevance with the current phenomenon, this research attempts to extend the conceptual model as well as the hypothesis which have been developed through scientific research to produce a new conceptual model (Agusty, 2006). The other things that the writers emphasized that the antecedent variables are a construct comprising proxies and have not been proven in an integrated model (never been tested before) especially the relation between work overload variable with the job satisfaction, so there is an originality in this writing, the writers expect to fill the gap of the previous researches, especially in developing the comprehension about burnout and the causality with the antecedent thereof. In general, this research is expected to produce an integrated conceptual model or a new extension approach to the previous model to produce a new comprehension. Based on the introduction above, the outline of the problem are as follows:

1. Does role conflict affect burnout directly?

2. Does intrinsic motivation affect burnout directly?

3. Does work overload affect burnout directly?

4. Does role conflict affect job satisfaction directly?

5. Does intrinsic motivation affect role conflict directly?

6. Does intrinsic motivation affect job satisfaction directly?

7. Does work overload affect job satisfaction directly?

8. Does Burnout affect job satisfaction directly? 


\section{THEORETICAL REVIEW}

According to Cordes and Dougherty (1993) in Babakus (1999) and Low (2001) that burnout consists of three dimensions which depicts psychology syndromes namely: Emotional exhaustion, depersonalization, and diminished personal accomplishment. The relation between the service givers and the receivers, according to Maslach (1980), is an asymmetric relationship. Emotional exhaustion symptom is identified by the drained energy, the deterioration of emotional source such as compassion, empathy and attention, which eventually cause a feeling of inability to give a good service to people. Depersonalization is an attitude, feeling as well as a negative perspective to service receivers (Maslach, 1996). This negative reaction is reflected in their attitude such as looking down on clients, cynical attitude towards clients, obnoxious and inhuman in their relationship with clients, or even ignoring the clients need (Maslach, 1982, 1993). Reduced personal accomplishment is indicated by the tendency to give negative evaluation towards him, especially anything related to work. Hence, those three dimensions are selected as burnout indicator.

Luthans (2002) defines role conflict as a position where we have an expectation to improve from the norm we developed. Further, Luthans (2002) describes role conflict through three main dimensions namely: Individual conflict with his own role, wherein this conflict occurs between the individual himself with his expectation of the job role. Intrarole conflict, wherein this conflict is caused by the contradiction of how a certain role must be performed. Interrole conflict, wherein this conflict is caused by the different requirements from two or more roles which have to be carried out at the same time. The indicator of role conflict which were used in this research were; (1) the relationship with the superiors, co-workers and staff, (2) the relationship with students, (3) the competition to seize structural position, (4) competing for certain course to teach and the schedule and (5) performing another role as a structural official at the same time.

Work overload is a part of the whole workload concept. Basically work overload is consisting of four dimensions which is one of the main causes of burnout (Gibson et al., 1996). The four dimensions are as follows: Quantitative overload, Qualitative overload, Quantitative underload, Qualitative underload. The indicator used to measure work overload are (1) perform various kind of education activities, (2) perform various kind of researches, (3) perform various kind of community services, (4) perform various another activities for the sake of improvement and (5) perform another role other than college lecturer namely structural staff or official.

According to Herzberg, (1996) in Robbins, (2002) who extends Maslow's hierarchy theory of needs, he extends the theory into two factors about motivation. The first factor is motivation factor also known as satisfier or intrinsic motivation and the other one is maintenance factors also known as disatisfier or extrinsic motivation. The satisfier factor also known as motivator is a factor to push someone hard enough to get a reward from himself (intrinsic), namely: Achievement, recognition, responsibility, advancement, the work itself and the possibility growth. Research indicator from intrinsic motivaton are; (1) having an interest in the work itself, (2) getting a recognition, (3) having a chance to learn something new, and getting a quick functional promotion is more certain if he do some functional position, (4) having a sense of responsibility and (5) have a motivation to improve the institution where he works.

Job satisfaction is some kind of feeling wanted by any employee. Job satisfaction can be defined as the different between the reality faced and the emotional condition of employee at work, both the good and the bad one. According to Robbins, (1996), job satisfaction refers to the general attitude of an individual to his job; therefore one with a high job satisfaction will show a positive attitude towards his job. In relation to this research, the job satisfaction factors are as follows, (1). The job is matching with the will and the skill of the employee. (2). There is an opportunity to get promotion, functional promotion or a better position. (3). Satisfying payment, honorarium and another benefits. (4) The support from co-workers, and superiors. (5). A good prestige related to a good reputation of his workplace has. 
The conceptual frames established in this research follows the way of thinking of the research model by Babakus et al., (1999), developed with the current phenomenon by adding motivation intrinsic variable which refers to Low et al., (2001) and Karatepe and Tekinkus, (2006) as well as adding work overload variable which refers to Zangladi, (2004).

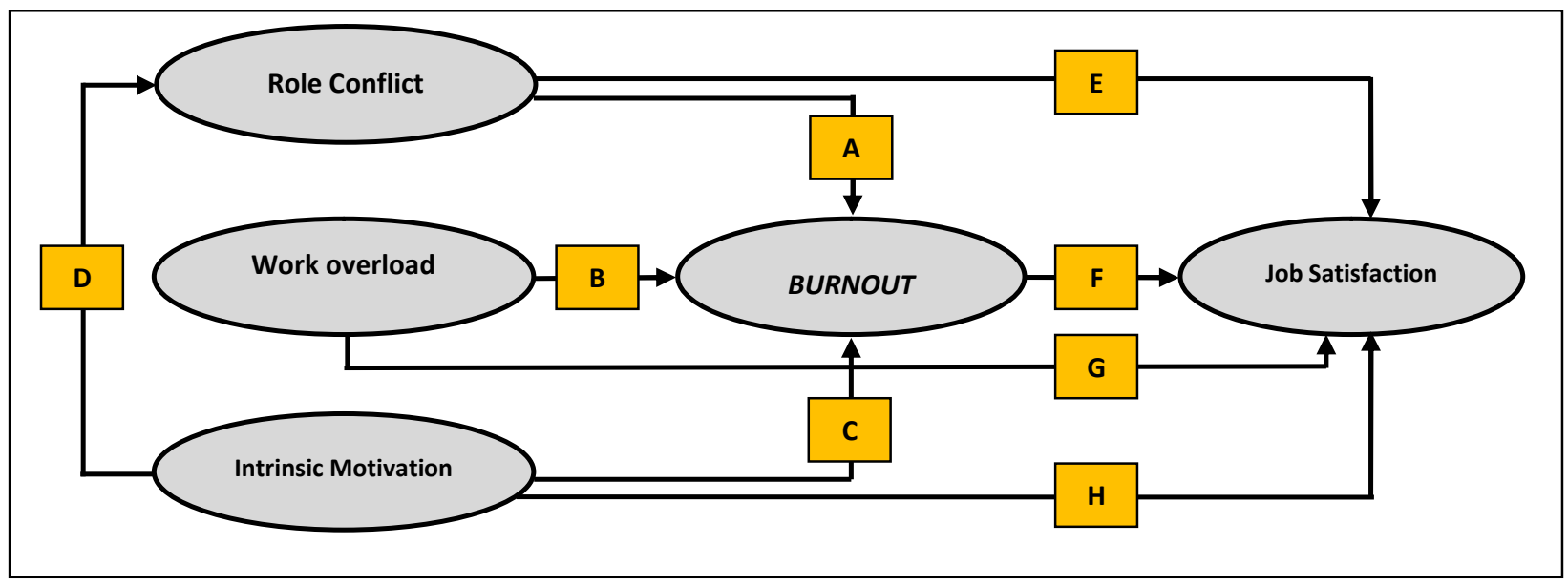

Figure 1 - Frames of Relationship Path between Variables

\section{METHODS OF RESEARCH}

Types of Research. Having been viewed from the purpose that will be achieved, this research was categorized into an explanatory research since it tried to explain a causal relationship between role conflict excessive workload and intrinsic motivation variable (anteseden variable). Burnout and working satisfaction and its influence are through hypothesis test (Sugiyono, 2009). An approach in this research includes in the quantitative research, in which it would be conducted an empirical study and assessment based on the existing theory. This research model was survey research model using questionnaire under the condition of getting individual opinion data of the respondent (Jogiyanto, 2008) as well as conducted hypothesis test.

Location and Time. This research was conducted at 6 (six) Private-Owned Universities (PTS) in the region of Ambon island which resides under the Kopertis Region XII (Maluku, North Maluku, Papua and West Papua). This research was undertaken at the end of February until the end of May 2011 with a time horizon of one-shot study or cross-sectional, in which the data was only once collected in a time period (Sekaran, 2006;177).

Population and Sample. The target population of this research was all lecturers who concurrently occupy a structural position at Private-Owned University (PTS) in the region of Ambon. While the sample population of this research consisted; (a) a lecturer who temporarily occupies structural position at 6 (six) Private-Owned University (PTS) in the region of Ambon island that has undertaken that structural duty for at least 1 (one) year and (b) a lecturer who is not certified yet. The reason to "limit" that sample population was to make the writers maintain their consistency with the postulate of the research hypothesis so that an individual who became analysis unit in this research was possible and proper to be drawn as a research sample (Sugiharto, Siagian, Sunaryanto and oetomo, 2001).

Sampling method of this research used Probability Sampling method since the number of population was known exactly by 126 lecturers. While sampling determination technique used was Multistage Cluster sampling technique. The research result conducted at the office of Kopertis Region XII shows that among the sample population (126 lecturers), those who actually have been certified were 21 lecturers and total questionnaire not coming back were 3 questionnaires so that the size of end sample to be analyzed was 102 respondents.

Source of Data and Data Collection Technique. The data of this research was primary and secondary data. Primary data collection was conducted using field research with data collection technique through spreading and filling a questionnaire and attending an interview. 
Analysis Method. In accordance with this research purpose, data analysis method was quantitative analysis, it was technically conducted in 2 parts of data analysis, i.e. validity and reliability test. While analysis technique used was using descriptive statistic analysis and inferential statistic analysis covering confirmatory factor analysis and path analysis.

\section{RESULTS AND DISCUSSION}

The Result of the Path Analysis. The Estimation of the entire path coefficient modeled in this research is depicted in table below.

Table 1 - The Summary of Path Coefficient

\begin{tabular}{|l|l|l|l|}
\hline Independent variable & Dependent variable & Beta coefficient & P value \\
\hline Intrinsic Motivation & Role Conflict & -0.227 & 0.022 \\
\hline Role Conflict & Burnout & 0.112 & 0.206 \\
\hline Work overload & Burnout & 0.466 & 0.000 \\
\hline Intrinsic Motivation & Burnout & -0.196 & 0.022 \\
\hline Role Conflict & Job satisfaction & -0.183 & 0.029 \\
\hline Work overload & Job satisfaction & -0.053 & 0.569 \\
\hline Intrinsic Motivation & Job satisfaction & 0.357 & 0.000 \\
\hline Burnout & Job satisfaction & -0.327 & 0.001 \\
\hline
\end{tabular}

Source Primer data, treated in 2011.

The table above explains that not all of the eight paths in the hypothesis model are significant. The dominant factor of burnout is work overload, while intrinsic motivation is the dominant factor of job satisfaction. In particular, both these dominant path became interesting as they will determine how an organization work. For further information, the result of the whole path analysis is depicted in the following figure.

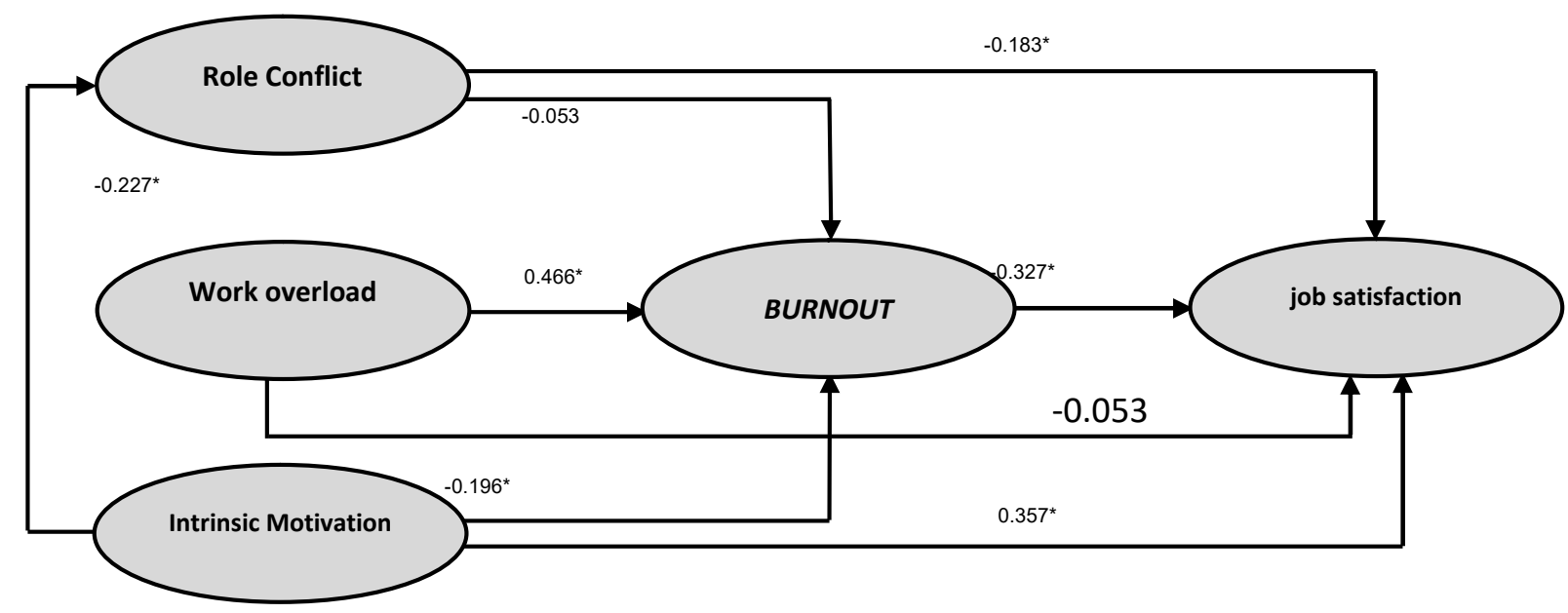

Source: Primer data, treated in 2011

Notes: ${ }^{* *}=$ Significant if $\alpha=0.05$ ns Insignificant if $\alpha=0.05$

Figure 2 - The Result of the Path Analysis

Model Accuracy. Hypothesis model accuracy from the research data measured from the relation from two coefficients of determination $\left(R^{2}\right)$ from the three equations. The first to third equation can be determined from $R^{2}{ }_{1}$ is $0.051, R_{2}^{2}$ is 0.365 and $R^{2}{ }_{3}$ is 0.458 . The result of model of accuracy:

$$
R^{2} \text { model }=1-\left(1-R^{2}{ }_{1}\right)\left(1-R^{2}{ }_{2}\right)\left(1-R^{2}{ }_{3}\right)=0.673 \text { or } 67.3 \%
$$

The $67.3 \%$ of model of accuracy calculation result explains that the contribution model to comprehend structural relationship from the five researched variables is $67.3 \%$ and the 
remainder are defined by other variables that are not in the model. This result also shows that coefficient of determination is well enough, as a result, this model is suitable to use and further interpretation is possible to be conducted. In order to express the extension to burnout model (as the topic of this research), the accuracy or the viability of this research also use trimming theory. With the use of trimming model, the insignificant path will be ignored, so that it will yield a new conceptual model supported by empirical data as a result (Solimun, 2005). The recommended conceptual model after the test of trimming model is depicted below.

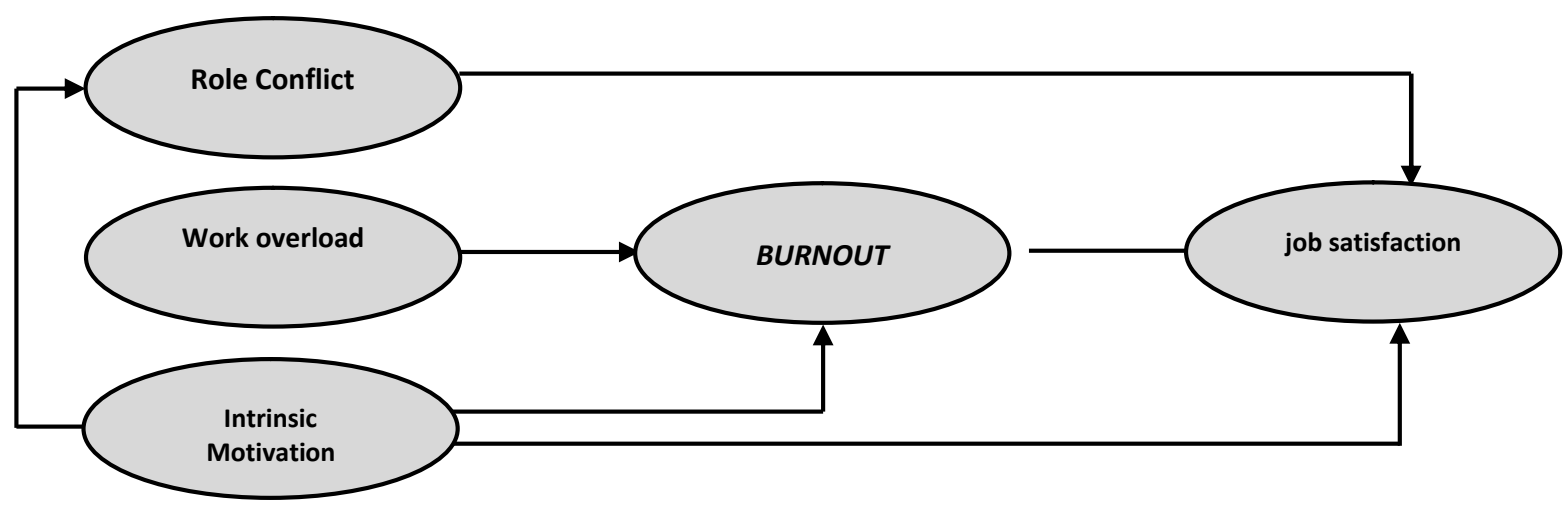

Figure 3 - The Result of Path Analysis after Trimming

The Result of Hypothesis Testing. The decision making to test the hypothesis uses significant value ( $p$-value) with the criteria: if $p$-value $>0.05$ then $\mathrm{H}_{0}$ is accepted or $\mathrm{H}_{a}$ is rejected and the path coefficient is not significant, and if $p$-value $<0,05$ then $\mathrm{H}_{0}$ is rejected or $\mathrm{H}_{\mathrm{a}}$ is accepted and the path coefficient is significant.

Testing of Hypothesis a: Hypothesis $\mathrm{H} 1$ states that role conflict has a positive value and significant to burnout level suffered by a college lecturer. The result of t-test to path coefficient in this relationship is 0.112 , which is insignificant ( $p$-value $=0.206$ ), consequently it can be concluded that the research data does not support the hypothesis $\mathrm{H} 1$ or in the other words, role conflict does not affect positively and significant to the burnout level suffered by the lecturer.

Testing of Hypothesis b: Hypothesis $\mathrm{H} 2$ states that role conflict has a negative value and significant to job satisfaction of a college lecturer. The result of t-test to path coefficient in this relationship is -0.183 , which is significant ( $p$-value $=0.029$ ), consequently it can be concluded that the research data supports the hypothesis $\mathrm{H} 2$ or in the other words, role conflict affects negatively and significant to the job satisfaction level of the lecturer.

Testing of Hypothesis $\mathrm{C}$ : Hypothesis $\mathrm{H} 3$ states that work overload has a positive value and significant to burnout level suffered by a college lecturer. The result of t-test to path coefficient in this relationship is 0.466 , which is significant ( $p$-value $=0.000)$, consequently it can be concluded that the research data supports the hypothesis $\mathrm{H} 3$ or in the other words, work overload affects positively and significant to the burnout level suffered by the lecturer.

Testing of Hypothesis d: Hypothesis $\mathrm{H} 4$ states that work overload has a negative value and significant to job satisfaction of a college lecturer. The result of t-test to path coefficient in this relationship is -0.053 , which is insignificant ( $p$-value $=0.569$ ), consequently it can be concluded that the research data does not support the hypothesis $\mathrm{H} 4$ or in the other words, work overload affects negatively but insignificant to the job satisfaction level of the lecturer.

Testing of Hypothesis e: Hypothesis $\mathrm{H} 5$ states that intrinsic motivation has a negative value and significant to role conflict of a college lecturer. The result of t-test to path coefficient in this relationship is -0.227 , which is significant ( $p$-value $=0.022$ ), consequently it can be concluded that the research data supports the hypothesis $\mathrm{H} 5$ or in the other words, intrinsic motivation affects negatively and significant to the role conflict of the lecturer.

Testing of Hypothesis $\mathrm{f}$ : Hypothesis $\mathrm{H} 6$ states that intrinsic motivation has a negative value and significant to burnout level of a college lecturer. The result of t-test to path 
coefficient in this relationship is -0.196 , which is significant ( $p$-value $=0.022$ ), consequently it can be concluded that the research data supports the hypothesis $\mathrm{H} 6$ or in the other words, intrinsic motivation affects negatively and significant to the burnout level of the lecturer.

Testing of Hypothesis g: Hypothesis $\mathrm{H} 7$ states that intrinsic motivation has a positive value and significant to job satisfaction of a college lecturer. The result of t-test to path coefficient in this relationship is 0.357 , which is significant ( $p$-value $=0.000$ ), consequently it can be concluded that the research data supports the hypothesis $\mathrm{H} 7$ or in the other words, intrinsic motivation affects positively and significant to the job satisfaction of the lecturer.

Testing of Hypothesis $\mathrm{h}$ : Hypothesis $\mathrm{H} 8$ states that burnout has a negative value and significant to job satisfaction of a college lecturer. The result of t-test to path coefficient in this relationship is -0.327 , which is significant ( $p$-value $=0.001$ ), consequently it can be concluded that the research data supports the hypothesis $\mathrm{H} 8$ or in the other words, intrinsic motivation affects negatively and significant to the job satisfaction of the lecturer.

Based on the rest result of intrinsic motivation to role conflict experienced by a college lecturer, there is a significant negative effect from intrinsic motivation to role conflict. Consequently, the better intrinsic motivation of a college lecturer, the lower role conflict level or it is able to be reduced to the lower level if the lecturer has a high intrinsic motivation. The result of the analysis data proves that the biggest contribution of intrinsic motivation comes from the institution where the lecturer works, which $97,1 \%$ of respondents agree with this. The second best contribution comes from the interest of the work itself, which $93,1 \%$ respondents support this statement. The third best contribution comes from a perception which the workload is fun and challenging $(94,1 \%)$. Those three factors have proven to have an influence to reduce role conflict experienced by the lecturer (negative effect). According to test result there is a stimulant to role conflict such as an obligation to multitask, not only they have to perform the Three Principle of Higher Education, but also they have to perform their job as structural officer, they are expected to make an accurate and quick judgment, while the bad relationship between co-workers because of the competition for structural position just make it worse. This research result is in line with Low et al., (2001) who states that the higher the intrinsic motivation, the lower the role conflict level. Hence, this research result justifies the important meaning of intrinsic motivation, especially in reducing role conflict level.

The other test result is intrinsic motivation affects burnout level of a college lecturer. Evidently, intrinsic motivation has a significant negative effect to burnout. Thus, a high level of intrinsic motivation will reduce burnout level. There are some indications to comprehend the contribution of dominant burnout experienced by a college lecturer concurrent with structural position at a PTS in islands of Ambon such as; $36,3 \%$ respondents state that they are very exhausted after they have finished their job of the day, $40,2 \%$ respondents state that they are not satisfied with what they have achieved. $23,6 \%$ respondents state they have worked too hard while $21,6 \%$ respondents state that they do not give enough attention to their main job because of exhaustion (physically and emotionally) and $17,7 \%$ respondents state that they do not have enough time to finish all of the given workload.

Based on the analysis result, the entire dimension of burnout level is negatively affected by intrinsic motivation. This research result also supports Low et al., (2001) who explains the higher intrinsic motivation, the lower the burnout level. This research also supports Karatepe dan Tekinkus, (2006) who describe intrinsic motivation have a significant negative effect to emotional exhaustion. The last test result from intrinsic motivation variable is about its effect on job satisfaction level. The intrinsic motivation affects the job satisfaction level of college lecturer in islands of Ambon.

The intrinsic motivation also significantly affects job satisfaction of the lecturer. This substantially means that motivation is related to lecturer interest to job and his perception to the job itself which is fun and challenging makes the lecturer satisfied because they feel as "someone who give contribution" which will attract support from co-workers and superiors. This result also supported by Low et al., (2001) who emphasized previous research by Sigh et al., (1994) and Babakus et al., (1999) who states that high intrinsic motivation level affects job satisfaction positively. While Karatepe dan Tekinkus, (2006) believe the same thing that 
intrinsic motivation has a significant positive effect to the job satisfaction. These findings also reinforce the importance of intrinsic motivation, not only for reducing the effect off role conflict as explained before, but also it is "significant" to reduce burnout level as well as improving job satisfaction.

Role conflict in this research model is indicated with the conflict in the relationship with superiors, co-workers, administration staff, students and the other similar conflicts such as competing with co-workers to get the structural position, competing for the course to teach and the difficulties in concurrent another position. The research result shows that role conflict does not affect burnout level. This result is also reinforced by interviewing a number of respondents who state that most of the lecturers do not really exhausted and have enough time, although they have to perform two roles at once. This result is contradict with Babakus et al., (1999) in the role of emotional exhaustion in sales force attitude and behavior relationship who explains that role conflict positively affect burnout. This result also does not support Low et al., (2001); Bhanugopan, (2006). The most recent empirical studies also give a supportive result, namely Hamwi et al., (2011) who study role conflict and burnout to 136 employees of advertising company in South America, shows a result that role conflict has a positive effect to emotional exhaustion. However, this result is not relevant with Zagladi, (2004) who states that role conflict does not affect emotional exhaustion (one of the dimensions of burnout).

Nevertheless based on the analysis, the intrinsic motivation also has a significant negative effect to job satisfaction of the lecturer who concurrent structural position at a PTS in islands of Ambon. Moreover, if the decision made by the lecturer in his capacity as structural officer are rejected often, his job satisfaction level will decrease because he is marking himself as failed person and feeling "does not have much contribution" especially in his workplace. The other example of role conflict is the suitable extra benefits that should be earned (i.e. extra payment or other benefits), while the lecturer who has two obligations, as a lecturer and structural officer, however, $44,1 \%$ respondents say that their payment and benefits are not suitable or too low, only enough for their normal daily needs. This conflict will definitely reduce their job satisfaction level. Another example of role conflict such as bad relationship between co-workers because of the competition to get structural position, also reduce job satisfaction level because they do not get support to work from them $(16,7 \%$ respondents support the statement). This research result is relevance with Dubisky et al., (1992); Moncrief et al., (1997); Babakus Emin et al., (1999); Brashear et al., (2000); Melenie et al., (2006); Harris et al., (2006) who state role conflict has negative effect to job satisfaction.

The research result shows that work overload have a significant positive effect to burnout. Hence, the higher the workload level, the lecturer are more prone to burnout. Based on a direct observation, there is a phenomenon wherein a college lecturer concurrent with structural position at a Private-Owned University (PTS) in islands of Ambon have more workload compared to the lecturer in a big PTS, especially the head of the faculty and the secretary thereof. They express that they are disturbed by the workload which are not actually their responsibility.

This research result is relevance with Shawn \& Weekly, (1985) who states that work overload affects perceive pressure; Zagladi, (2004) justifies that work overload has a positive effect to emotional exhaustion and Bhanugopan, (2006) that describe role overload has a positive relationship with all of the dimensions of burnout (emotional exhaustion, depersonalization and reduced personal accomplishments). This result also supported by most recent empirical research by Henkens dan Leenders, (2010) and Izquierdo et al.,(2010) that explain all of the dimensions of burnout are affected by excessive workload.

Furthermore, the research result shows that work overload does not affect the job satisfaction level of the lecturer. The reason is that work overload is more expressed by factors related to their role (as a lecturer and structural officer) which already match with their will and their skill, as well as the payment, benefits, support and their relationship with coworkers and superiors. This is a new finding (originality) because there are many previous research, such as Shaw James B., and Weekly Jeff A., (1985); Zagladi, (2004) and 
Bhanugopan, (2006), however, none of them ever research about the relation between variables with job satisfaction especially to use sample as college lecturer. This finding is expected to give a contribution to conceptual model development in this research, so that a new model is eventually suggested based on this model.

The research result of burnout influence towards job satisfaction of a lecturer shows that burnout negatively affects job satisfaction or in the other words, the higher burnout level the lower job satisfaction level of a lecturer who is concurrent structural position at PrivateOwned University (PTS) in islands of Ambon. Based on the result of the interviews, 36,3\% respondents state that they feel very exhausted from work, they do not satisfied to work for the next day because they still physically and emotionally tired. This has caused the lecturer cannot effectively perform their duties.

Another finding based on data tabulation, 40,2\% respondents states that they are dissatisfied with what they achieve wherein $33,4 \%$ of them express that they do not get necessary support from co-workers. Moreover, $41,3 \%$ respondents state that they have excessive workload and they work too hard for that. These findings show that the lecturer already experienced burnout (they are obliged to do an excessive workload and they try too hard to carry them out within the given time, exhausted, and eventually give a minor attention to their main duty). As for the consequences, this will affect job satisfaction, where the monthly check and benefits are lower compared to other people with the same position at a bigger PTS, while there is an unfair promotion that involves insider threat. This result is relevant with the previous research such as; Babakus et al.,(1999) who describes burnout have a negative effect to job satisfaction, Low et al., (2001) that states the higher the level of burnout, the lower job satisfaction level. In addition, by using the same research sample (Lecturer of PTS') by Zangladi, (2004) states similar result that a high level of emotional exhaustion negatively affects job satisfaction and Kuruuzum et al., (2008) that proves the strong involvement of depersonalization to job satisfaction.

The Implication of Research Result. The implication of the model not only has answered the problem and the purpose of this research but also has solved the research gap as well as the originality of this research which will be explained below.

The research result shows that intrinsic motivation affects role conflict, burnout and job satisfaction level. This finding reinforces the other past researches such as Sigh et al., (1994), Babakus et al., (1999), Low et al., (2001), Karatepe and Tekinkus, (2006).

Role conflict does not affect burnout level but affects job satisfaction level. This finding also has answered research gap related to the ambivalence of empirical research study of the influence of role conflict to burnout level by Babakus et al., (1999), Low et al., (2001), Zagladi (2004) and Hamwi et al.,(2011). While the finding about role conflict affecting job satisfaction level supports the research result by Dubisky et al., (1992), Moncrief et al., (1997), Babakus et al., (1999), Brashear et al., (2000), Lankau et al., (2006) and Harris et al., (2006).

Work overload affects burnout level but does not affects job satisfaction level. The finding about work overload affecting burnout level is relevance with the research result by Shawn \& Weekly, (1985), Zagladi, (2004), Bhanugopan, (2006), Henkens and Leenders, (2010) as well as Izquierdoet al.,(2010). Furthermore, it is necessary to emphasize this research about the quality of the relationship between workload and satisfaction level is evidently an original result or the originality thereof, as a response of Lankau's et al., (2005) suggestion. Researching the causality between the two variables, the writers prove the extension of burnout antecedent model and its consequences to job satisfaction level have been conducted.

This last part of research result shows burnout affects job satisfaction level. These findings reinforce the other past researches by Babakus et al., (1999), Low et al., (2001) Zagladi, (2004) and Kuruuzum et al., (2008).

The managerial implication as a consideration to make a better policy for PTS superiors in islands of Ambon based on these research findings are as follows:

This research explains intrinsic motivation of the lecturer concurrent with structural position at a PTS in islands of Ambon is in a good level. Therefore for the superiors at PTS in 
islands of Ambon should maintain it to open a better opportunity to career development, give wider authority of obligation and the chance to get an achievement to improve the PTS itself. This kind of policy will certainly reduce the high level of role conflict and burnout, as well as improving job satisfaction level.

The research result finds that the lecturer at PTS in islands of Ambon do not suffer from an excessive workload, but there might be a slight chance that this low level of work overload still cause burnout. The superiors of PTS in islands of Ambon should take these findings seriously by giving a policy such as more flexibility in arranging teaching schedule or academic consultation with their student. It is recommended to support this policy by giving a better benefits to the lecturer who is concurrent structural position.

This research also shows the lecturer who concurrent structural position at PTS in islands of Ambon does not experience burnout but this low level burnout still affect their job satisfaction. This kind of policy gives a better chance to the lecturer to use their skill effectively in doing their role; they will also give more significant feedback to create a better culture in their workplace which will certainly reduce the burnout level.

Research Limit. The writers have faced several research limits during the research. The research limits of this research are as follows:

The research sample only involves PTS lecturer who is concurrent with structural position in islands of Ambon and cannot be generally applied to another lecturer, especially in Kopertis XII Region.

This kind of research, in order to comprehend the perception and the attitude of the respondents by using questioner as a technique to collect data, the question should be managed well to get a relevance answer.

This research designed in a form of cross-section is unable to comprehend the change of a number of aspects related to the content of this research, so that it might be irrelevant for longer periods of time.

This research is limited to the extension of variables thereof to produce a new model. Other variables such as commitment, performance and the will to stay or giving in to resign can be used to develop this research even further.

\section{REFERENCES}

1. Agusty, F. 2006. Metode Penelitian Manajemen: Pedoman Penelitian Untuk Penulisan Skripsi, Tesis Dan Disertasi IImu Manajemen. Second Edition, Badan Penerbit Universitas Diponegoro, Semarang, Semarang.

2. Babakus, E., Cravens, D., Johnston, M., Moncrief, W. C. 1999. The Role of Emotional Exhaustion in Salesforce Attitude and Behavior Relationship. Journal of the Academy of Marketing Science, Vol. 27, No. 1, pp. 58-70

3. Bhanugopan, R. 2006. An Empirical Investigation of Job Burnout among Expatriates. Empirical Investigation of Job Burnout, Vol. 35, No. 4, pp. 449-468

4. Boles, J. S., Mark, W. J., dan Joseph, F. H. 1997. Role Stress Work-Family Conflict and Emotional Exhaustion; Inter-Relationship and Effecf on Work Related Consenquences. Journal of Personal Selling and Sales Management (winter), pp. 17-28

5. Brashear, T. G., Rosenberger III P. J., Brooks, C. M., Acevedo, C. R. 2000. A Test of Retail Salesforce Turnover in Romania. ANZMAC 2000 Visionary Marketing for the $21^{\text {st }}$ Century; Facing the Challenge.

6. Brewer, G. 1994. Mind Reading: What Drives Top Salespeople to Greatness? Journal of Sales and Marketing Management, Vol. 146, May, pp. 82-8

7. Cordes, C. L. \& Dougherty, T. W. 1993. A Review of an Integration of Research on Job Burnout, Academy of Management Review, Vol. 18, pp. 56-621

8. Day, R. \& Allen, T. 2002. Why are Proteges More Successful: Explaining the MentoringCareer Success Relationship.Paper presented at the 17 th Annual SIOP Conference, Toronto, ON. 
9. Dubisky, A. J., Michaels, R. E., Katobe, M., Un L. C., Cheol, M. H. 1992. Influence of Role Stress in Industrial Salespeoples Work Outcomes in The United States, Japan and Korea. Journal of International Business Studies, Vol. 23, No. 1, pp. 77-99

10. Gibson, J. L., Ivancevich, J. M. \& Donelly, J. H. 1996. Organisasi: Perilaku, Struktur, Proses, Jilid 1 dan 2. Binaputra Aksara, Jakarta.

11. Hamwi, G. A., Rutherford, B.N. \& Boles, J. S. 2011. Reducing Emotional Exhaustion and Increasing Organizational Support. Journal of Business \& Industrial Marketing, Vol. 26, No. 1 , pp. 4-13

12. Harris, E. G., Artis, A. B., Walters, J. H., Licata, J. W. 2006. Role Stressors, Service Worker Job Resourcefulness, and Job Outcomes: An Empirical Analysis. Journal of Business Research 59, pp. 407-415

13. Henkens, K. \& Leenders, M. 2010. Burnoutand Older Workers Intentions to Retire. International Journal of Manpower, Vol. 31 No. 3, pp. 306-321

14. Izquierdo, L. G., Moreno, B. \& Izquierdo, M. G. 2010. Applying Information Theory to Small Groups Assessment: Emotions and Well-Being at Work. The Spanish Journal of Psychology, Vol. 13 No. 1, pp. 309-328

15. Jogiyanto. 2008. Metodologi Penelitian Bisnis: Salah Kaprah dan PengalamanPengalaman, First Edition, BPFE - Yogyakarta, Yogyakarta.

16. Karatepe, O. M. \& Tekinkus, M. 2006. The Effects of Work-Family Conflict, Emotional Exhaustion and Intrinsic Motivation on Job Outcomes of Front-Line Employees. Journal Internasional Bank Marketing, Vol. 24, No. 3, pp. 173-193

17. Kuruuzum, A., Anafarta, N. dan Irmak, S. 2008. Predictors of Burnout among Middle Managers in the Turkish Hospitality Industry. International Journal of Contemporary Hospitaly Management. Inj. 20, No. 2, pp. 186-198

18. Lankau, M. J., Carlson, D. S., Nielson, T. R. 2006. The Mediating Influence of Role Stressors in the relationship between Mentoring and Job Attitudes. Journal of Vocational Behavior, 68, pp. 308-322

19. Lee, R.T. \&Ashforth, B.E. 1996. A Meta-Analytic Examination of the Correlates of the Three Dimensions of Job Burnout, Journal of Applied Psychology, Vol. 81 No. 2, pp. 33123

20. Licata, J. W., Mowen, J. C., Harris, E. G., Brown, T. B. 2003. On The Trait Antecedents and Outcomes of Service Worker Job Resourcefulness: A Hierarchical Model Approach. Journal Acad Mark Sci. Inj. 3, pp. 71-256

21. Low, G. S., Cravens, D. W., Grant, K., Moncrief, W. C. 2001. Antecedents and Consequences of Salesperson Burnout. European Journal of Marketing-Salesperson Burnout, Vol. 35, No. 5/6, pp. 587-611

22. Luthans, F. 2002. Organizational Behavior, Ninth edition, McGraw-Hill, New York.

23. Maslach, C. \& Susan, J. E. 1981. The Measurement of Experienced Burnout. Journal of Occupational Behavior, pp. 99-113

24. Maslach, C. 1982. Understanding Burnout; Definitional Issues in Analyzing a Complex Pheomenom in Paine, W. S. (ed), Job Stress and Burnout, Beverly Hills, Sage Publications.

25. Maslach, C. 1982. Burnout the Cost of Caring, Prentice-Hall inc, New Jersey.

26. Maslach, C. 1986. Burnout Research in the Social Services: A Critique. Journal of Social Service Research, Vol. 10, 95-105.

27. Maslach, C. 1993. Burnout; A Multidimensional Perspective in Schaufeli, W. B., Maslach, C. dan Marek, T., (ed), Professionals Burnout; Recent Development in Theory and Research, Taylor \& Francis, Washington DC.

28. Moncrief, W. C., Babakus, E., Cravens, D., Johnston, M. 1997. Examination the Antecedent and Concequences of Salespeoples Job Stress. European Journal of Marketing-Examining Salesperson Job Stress, Vol. 31, No. 11/12, pp. 786-798

29. Perrewe, P. L., Hochwarter, W. A., Rossi, A. M., Wallace, A., Maignan, I., Castro, S. L., Ralston, D. A., Westman, M., Vollmer, G., Tang, M., Wan, P., Van Deusen, C. A. 2002. Are Work Stress Relationships Universal? A Nine-Region Examination of Role Stressors, General Self-Efficacy, and Burnout. Journal of International 8, pp. 163-187 
30. Robbins, S. P. 2002. Prinsip-Prinsip Perilaku Organisasi (Translated by Halida \& Dewi Sartika), Fifth Edition, Erlangga, Jakarta.

31. Sekaran, U. 2006. Research Methods for Business - Metodologi Penelitian Untuk Bisnis (Translated by Kwan Men Yon), Book 1, Edition 4, Salemba Empat, Jakarta.

32. Sekaran, U. 2006. Research Methods for Business - Metodologi Peneltian Untuk Bisnis (Translated by Kwan Men Yon), Second Book, Fourt Edition, Salemba Empat, Jakarta.

33. Shaw, J. B., Weekly, J. A. 1985. The Effect of Objective Work Load Variations of Psychological Strain and Post Work Load Performance. Journal of Management, Vol. 11, No. 1 , pp. $97-108$

34. Sugiharto, Dergibson, S., Lasmono, T. S. \& Denny, S. O. 2001. Teknik Sampling, PT. Gramedia Pustaka Umum, Jakarta.

35. Sugiyono, 2009. Statistika Untuk Penelitian, Cetakan Kelima Belas, CV. Alfabeta, Bandung.

36. Solimun, 2005. Overview Metodologi Penelitian Kuantitatif. Handout, Class of Research Methodology, Universitas Brawijaya.

37. Sweeney, J. T. dan Summers, S. L. 2002. The Effect of The Busy Season Workload on Public Accountants's Job Burnout. Behavioral Research in Accounting, Vol. 14, pp. 236.

38. Zagladi, A. L. 2004. Pengaruh Kelelahan Emosional Terhadap Kepuasan Kerja dan Kinerja Dalam Pencapaian Komitmen Organisasional Dosen Perguruan Tinggi Swasta. Unpublished Dissertation, Universitas Brawijaya. 